\title{
Resource nationalism or resource liberalism? Explaining the Australian approach to Chinese investment in its minerals sector.
}

\author{
Paper presented at $4^{\text {th }}$ Oceanic Conference on International Studies \\ University of Auckland, 30 June 2010 \\ Jeffrey D. Wilson \\ Department of International Relations \\ Australian National University \\ jeffrey.wilson@anu.edu.au
}

\section{Abstract:}

Since 2005, a burgeoning wave of Chinese investments has set off a new 'minerals boom' in the Australian iron ore and coal mining sectors. While normally a welcome development for a host country, the state-owned character of the investing Chinese firms, and the 'strategic' rather than 'commercial' nature of their investments, has led to debate in Australia regarding how this process should be managed. Concurrently, in early 2008 the Australian government indicated an intention to more closely screen investments in its mineral sector "in the national interest", with a number of Chinese proposals subsequently either rejected or made conditional upon specific commitments. Both supporters and detractors alike have claimed this approach suggests an emerging 'resource nationalism' - an attempt to subject marketbased economic processes to political control for national developmental purposes - in Australian policy towards its minerals trade and investments with China.

This paper challenges this understanding, through an examination of the political economy characteristics of Chinese foreign mining investments, the dilemmas these present to the Australian government, and the relatively restrained nature of its response as seen in its recent FDI screening decisions. Through this evidence, Australian policy responses will be explained as a defensive move against the potential for non-market behaviour resulting from the state-directed character of the Chinese investors, rather than any national program to politically control minerals trade and investment. On the basis of this discussion, this paper will argue that Australian policy instead evidences a 'resource liberalism' approach, that attempts to ensure that the governance of its minerals trade and investment with China remain firmly as market-based processes. 


\section{Introduction}

For the first time in over a decade, foreign ownership of the mining industry has again become a political issue in Australia. Set off by a massive rush of foreign direct investment (FDI) from Chinese companies into the iron ore and coking coal sectors, and a tightening of its approach to FDI screening made in response in February 2008, Australia has re-opened a debate last settled in $1992^{1}$ on how to best manage foreign firms operating in the mining industry. Unlike previous debates, however, the contemporary controversy is focussed solely on one kind of mining investment - that made by state-owned Chinese investors - and concerns surrounding risks associated with their state-ownership. Despite disagreement over the appropriateness of the newly tightened FDI regime, both its supporters and detractors have characterised it as an example of resurgent 'resource nationalism' targeted against China. The issue has also quickly escalated to the top of the agenda in the ongoing Australia-China free trade agreement negotiations, and their diplomatic relations more broadly. Notwithstanding the repeated attempts by the Australian Government to dispel the notion, the belief that resource nationalism is on the rise in Australia has not abated - the issue of debate being over the appropriateness, rather than the existence, of such a change.

But is resource nationalism an appropriate way to understand Australia's recent approach to Chinese investment in its mining sector? This paper disputes this interpretation, and instead offers the perspective that recent changes to the modus operandi of Australian FDI screening are essentially 'liberal' in character. First, this paper will consider nationalistic and liberal methods of natural resource management, and outline the contours of the debate over Australia's recent approach to Chinese investment. Then, an analysis of the political-economic context of state-led Chinese FDI in the Australian mining sector, the formal content of the recent Australian policy change, and the means by which this policy has been implemented, will be offered. Through this analysis, it will be argued that Australian FDI screening can be explained as defensive regulations made to solely mitigate the risk of 'strategic' behaviour by state-owned Chinese

\footnotetext{
${ }^{1}$ The last major change to Australian FDI policy regarding mining occurred in 1992, when the Keating Government removed special rules for the industry under its broader One Nation program of economic liberalisation.
} 
investors. Finally, an explanation of these policies as consistent with a liberal rather than nationalistic approach to FDI will be offered.

National management of natural resources - resource nationalism and liberalism

In a globalised world economy, the management of natural resource endowments poses choices for resource-rich states. A consequence of economic globalisation and the international fragmentation of industries is that the spatial link between patterns of production and consumption are increasingly broken. Nowhere is this more true than in industries based on natural resource extraction, where owing to the arbitrary spread of resources around the globe, centres of production and consumption have become located in different national spaces. In this international economic context, resource-rich states must make difficult decisions over how natural resources, over which they have controls, are managed. On the one hand, owing to the necessity of international trade and investment flows, the development of export-oriented resource industries requires such states to allow for a degree of openness to international markets for goods and capital when making policy regarding the use of natural resources. On the other, the economies of resourcerich states are often underdeveloped, and/or dependent on the exploitation of natural resources. As a result, pressures exist to leverage these endowments for development purposes through the use of various forms of 'interventionist' economic policy that seek to maximise the national share of the gains accruing from natural resource exploitation (Moran, 1992). Put another way, resource-rich countries face choices between competing political-economic methods for the management of natural resources - as Gilpin (1987) has put it, a choice between state-based and market-based systems of economic allocation. In seeking to understand these national policy choices, we can divine two contrasting national types of natural resource management based on their employment of political- or market-based mechanisms of economic allocation - resource nationalism and resource liberalism.

Resource nationalism embodies an inherently state-directed and mercantilistic approach to the management of natural resources. It occurs where a country, endowed with natural resources needed by other countries, uses its legal jurisdiction over these resources to achieve some set of national goals that would otherwise not obtain if their exploitation were left to international market processes. It is rationalised by the idea that 
natural resources are scarce assets in the international economy, which if left by laissez-faire policies to market processes (such as exploitation by multinational corporations) will not be developed in ways that offer maximum benefits for the national economy (Maizels, 1992). Instead, it is argued that states should use selective, interventionist policies to achieve higher levels of local payoffs (Moran, 1971). While a wide range of national payoffs might in principle be pursued, four specific goals, with corresponding policy tools, have tended to be pursued by states engaged in resource nationalism:

- Enlarging the profits from resource exploitation by mandating increases in the traded prices of commodities, through the use of export controls and/or participation in international commodity cartels (Gilbert, 1995);

- The capture of these profits by insisting a degree of local ownership of projects, through the use of either FDI controls or in extreme cases outright nationalisation (Mares, 2010);

- The establishment of manufacturing activities by requiring that corporations engage in local processing of resources, through bargaining with foreign corporations (Moran, 1971); and

- The extraction of other (non-resource related) concessions from customer states, through the use of various forms of 'resource diplomacy' (Arndt, 1974).

Despite pursuing different goals, all four forms of resource nationalism are united by their political economy characteristics. Their significance is that they all involve taking the economic processes of resources extraction, processing and distribution 'out of the international market', by subjecting them to some kind of nationally-oriented control for politically defined goals. While such efforts are likely to be resisted by both customer states and the multinational corporations involved in resource exploitation, in situations where the resource-rich state possesses bargaining power over these partners it is able to use such policies to extract greater benefits than would have otherwise been the case (Moran, 1985).

Resource liberalism provides an alternate national method of natural resources management, and in one sense can be defined simply as an eschewal of such policies. However, it is more than just a negation of resource nationalist policies; and instead involves a state relying primarily on international market 
mechanisms for the development of its natural resources, through relatively unrestricted trade and investment policies. In the contemporary setting, it draws on neoliberal economic ideas regarding the efficacy of 'free' markets (Haselip \& Hilson, 2005), and is rationalised by the argument that maximum benefits from natural resources are enjoyed by states when they are developed as fully as possible to serve international markets (Hay, 2009). It involves a competing range of policies, including ${ }^{2}$ :

- $\quad$ Openness to FDI, to make use of foreign sources of capital for natural resource development;

- Actively pursuing MNCs, which bring packages of capital, technical skills and marketing channels, and can better develop natural resources than local firms;

- Avoiding placing conditions (such as for local processing) on firms, which might encourage MNCs to locate in other countries; and

- $\quad$ Politically assuring trade partners of reliability as a supplier through a liberal trade and investment regime.

Thus, the defining political economy characteristic of resource liberalism is that it places the processes involved in the development of natural resources squarely 'in the international market'. While this involves eschewing opportunities to extract greater gains, its advocates argue that in cases where resource-rich countries are in competition for global markets and sources of capital, such a range of policies will achieve better results than their corresponding nationalistic alternatives (Filho, 2002; Haselip \& Hilson, 2005).

Of course, these articulations of nationalistic and liberal formulations exist as ideal types of possible stateor market-based means of developing natural resources. In practice, few states policies fully express either, and some mix combinations of the two. For example, during the 1970s Brazil favoured the goals of state ownership and local processing (Ohara, 1974); Canada pursued national (but private) ownership requirements while leaving trade relatively free (Jenkins, 1986), whereas Australia has regulated both trade and ownership (Owen, 1988); and the OPEC countries favoured cartel-backed price interventions (Vernon,

${ }^{2}$ This discussion draws on articulations of the liberal approach made by Kumar (1990), World Bank (1992) and Filho (2002). 
1983). Historically, the 1970 s were a high water mark for resource nationalism as resource-rich states bargaining power increased in buoyant world markets, with the formation of the OPEC cartel, the formation of various international commodity agreements between producer countries, and a 'nationalisation wave' of Latin American metals industries (Moran, 1974; Rodrik, 1982). As world markets deteriorated during the 1980 s and 1990s, and supplier countries had to work harder to attract capital and win markets, these policies generally gave way to more liberal approaches (Bremmer \& Johnston, 2009; Maponga \& Maxwell, 2001). However, some observers fear a recent renaissance of resource nationalism in the energy field, led by Venezuelan and Russian approaches to oil and gas respectively (Bochkarev \& Austin, 2007), and a new round of Chinese 'energy diplomacy' that has actively co-operated and rewarded such efforts emanating from supplier countries in Africa and the Latin America (Downs, 2004; Kreft, 2006; Zweig \& Bi, 2005). Indeed, after two decades of relatively liberal policy, some have argued that Australia's approach to its gas and uranium sectors is, consistent with this world trend, also taking a turn back towards nationalism (Hay, 2009).

In light of such competing approaches to natural resources management, and the context of a possible resurgence of resource nationalism at a global level, this paper is concerned with a recent case of purported resource nationalism - Australia's 2008 tightening of its FDI controls, targeted at minerals investments by Chinese companies. Where does this tightening sit on the spectrum of natural resource policies? As an inherently 'political' intervention into otherwise market-based investment flows, is this evidence of growing resource nationalism in Australia? Or, given the context of the state-led Chinese investments that it has sought to regulate, might it be better understood as an inherently 'in the market' liberal approach? Through a detailed case study of recent Chinese minerals investments in Australia, and the policy changes made in response, these questions will be answered.

\section{The Australian controversy - Debates over Chinese investment in the mining sector}

In recent years, the question of Australian regulation of Chinese FDI in its mining sector has become a significant political issue, both within internal debates over economic policy and at the international level of Sino-Australian bilateral relations. This issue is relatively new, and was catalysed by a rush of Chinese 
FDI into the Australian mining industry since 2005. Much of this investment has been driven by demand for iron ore and coking coal from China's rapidly growing steel industry, and is part of a broader Chinese effort to secure foreign sources of minerals and energy to meet industrial demand which increasingly cannot be met by domestic reserves (Wu, 2005).

While normally a welcome development, these investments have became a source of much disquiet owing to the state-owned nature of the Chinese investors - which have typically been either Chinese state-owned enterprises (SOEs) or sovereign wealth funds (SWFs). Concerns have thus been raised over the concomitant risk that these firms would act in a policy-driven and 'strategic' manner, prioritising Chinese developmental needs above Australia's; as well as fears that such investments would give the Chinese government some measure of 'control' over the Australian mining industry. Following a number of highprofile investments in 2007, such worries reached fever-pitch in January 2008 when Chinalco, a Chinese state-owned mining conglomerate, intervened in the attempted takeover of Rio Tinto by BHP Billiton through a massive AUD 15.5 billion "dawn raid" on the London-listed shares of Rio Tinto, with the backing of China's State Council, but without the required approval of the Australian foreign investment regulator ${ }^{3}$

A response quickly followed, coming seventeen days later when the Australian Treasurer issued an updated set of guidelines for the review of foreign investments. While these guidelines did not involve any legislative changes to the FDI regime, they promised that under the existing rules allowing for screening of investments "in the national interest", closer scrutiny would now be applied to investments made by foreign government-owned entities (Department of Treasury (Aust.), 2008; Swan, 2008f). Despite not explicitly mentioning either Chinese SOEs or the minerals sector, its timing in the wake of the intervention in the BHP-Rio takeover meant it was widely interpreted as a warning against this type of investment activity ${ }^{4}$. This interpretation was reinforced when the Treasurer reiterated the policy regarding state-owned investors

\footnotetext{
3 "Rio just an investment, Chinalco says", Sydney Morning Herald, 5 February 2008; "Chinese keen for slice of BHP", Sydney Morning Herald, 11 June 2008.

4 "China faces mining investment curbs", The Australian, 26 June 2008; "Rio warns against tough stand on foreign cash", Sydney Morning Herald, 17 June 2008.
} 
in speeches on Sino-Australian relations to audiences in both Australia and China in June 2008 (Swan, 2008a, 2008b, 2008c). Though promising nothing new in terms of formal regulation, the Australian government was sending a clear political signal that it was concerned about the issue of Chinese stateowned investment in its mineral sector, and was stepping up its regulatory scrutiny in turn.

Making good on this promise, the screening of Chinese investments by Australia's Foreign Investment Review Board (FIRB) was immediately tightened, when in April 2008 the FIRB asked that ten Chinese mining investment applications be resubmitted in order to provide additional information related to concerns surrounding their state-ownership ${ }^{5}$. While the bulk of these applications (and those subsequently lodged) were ultimately approved, between April 2008 and March 2010 some four Chinese investments in the Australian minerals sector have been rejected, and another five approved subject to behavioural conditions $^{6}$. This heightened scrutiny of Chinese investment has proven controversial both within Australia and in China. Some involved parties have argued that the current regime fails to adequately protect Australia against the intrusion of the Chinese government into its mining industry; while others have denounced the policy as discriminatory against Chinese investors and/or potentially putting Australia's participation in a new China-driven global minerals boom at jeopardy.

Groups within Australia calling for an even greater scrutiny of Chinese investment on nationalist grounds come from a disparate range of political and ideological backgrounds. At the Federal Parliamentary level, both the Conservative Opposition (to the right of the Government) and the Australian Greens Party (to its left) have argued that allowing the Chinese (Communist) government to invest is resulting in a loss of national control over the minerals sector $^{7}$; and the two groups formed an (ideologically rare) alliance to force the government to call a Senate enquiry into the issue in March $2009^{8}$. More strangely, the Premier of Western Australia - a state whose economy is traditionally dependent on mining and stands to gain the most

\footnotetext{
5 "China told by Rudd Government to shelve mine deals", The Australian, 25 April 2008.

${ }^{6}$ Valid at the time of writing. Details of rejections and conditional approvals will be discussed in greater detail below.

7 “Joyce turns to television to undermine Chinalco bid”, Sydney Morning Herald, 17 March 2009;

“Australian opposition wants China deal blocked”, Reuters, 1 May 2009.

8 “Rudd Threatened by Australian Backlash to China's Rio”, Bloomberg News, 27 March 2009.
} 
from Chinese investment - also joined these calls, claiming Australia could be "overwhelmed" by Chinese investors ${ }^{9}$; and promised that the state government would take action to ensure Chinese firms do not "take control" of the state's mining sector from Australian interests ${ }^{10}$. Such attitudes appear to be widespread among the business community, with surveys conducted in early 2010 finding that most Australian investors are wary of allowing additional Chinese ownership of the Australian mining industry due to its state-owned nature. While most of those surveyed were content with the current regime as offering adequate protection against such risks, a sizeable minority (19\%) felt no further investment by Chinese SOEs should be allowed at all ${ }^{11}$. For its part, BHP Billiton argued that had it not been for the recent tightening of scrutiny, Australia would be risking the loss of ownership of the "underlying asset" behind the present minerals boom to foreign (Chinese) owners (Argus, 2009), though this somewhat reflects its interest in being protected against competition from new, Chinese-funded mining projects. Regardless of their level of satisfaction with the post-2008 approach, what unites these disparate groups is an understanding of the issue as one regarding the national control the Australian mining industry, with a clear 'resource nationalistic' preference for restrictions aimed against China.

Australian opponents of the Government's post-2008 approach similarly believe that it embodies emerging resources nationalism, though the argument has been deployed as part of calls for less, rather than more, state regulation. In mid-2008, the Australia-China Business Council argued that the heightened scrutiny and disquiet over national control were having the effect of deterring Chinese investors from Australia ${ }^{12}$; and was joined later in the year by a group of investment banks ${ }^{13}$ who argued that in the context of the global financial crisis the need for Chinese capital outweighed such concerns. A number of Australia-based mining firms have also joined these calls, though many of the critics of the current regime (in particular, Rio Tinto and Fortescue Metals Group ${ }^{14}$ ) tend to be those that have actively sought Chinese investors and

\footnotetext{
9 “Chinese need rules: WA Liberal Premier Colin Barnett”, The Australian, 26 September 2008.

10 "Beijing won't exploit us: Barnett”, The West Australian, 20 February 2009.

11 "Investors wary of Chinese money”, Sydney Morning Herald, 28 February 2010; “Most wary of China's big spend”, Australian Financial Review, 22 February 2010.

12 "Australia must track China resource interest or lose", The Australian, 17 September 2008.

13 "Calls to ease 'national interest' takeover defence”, The Australian, 29 October 2008.

14 “Albanese's close eye on Chinese predators", The Australian, 17 June 2008; "Twiggy's vision for foreign investment in Australia 01/04/2009”, ABC Radio National, 1 April 2009.
} 
have an interest in lobbying for a less restrictive regime. More radical accusations were made by Clive Palmer, a Queensland mine developer who labelled the Government's approach as avowedly discriminatory against Chinese on the basis of race $^{15}$.

No less critical has been the response from the affected parties in China. For their part, the involved Chinese firms have claimed their investments are 'commercially-oriented', and rejected any suggestion their activities reflect Chinese governmental priorities ${ }^{16}$. Additionally, while the Chinese Government has expressed ill-ease about the FIRB screening process for some time (for example, see MOFCOM, 2005), the issue appears to have escalated to the level of inter-state relations since the announcement of tougher scrutiny. Chinese negotiators moved to make the issue of FIRB screening their top priority during the SinoAustralian FTA negotiating rounds conducted in June and September 2008 (DFAT, 2009); and the Chinese Ambassador took the unprecedented step of publishing an opinion piece in an Australian broadsheet newspaper in April 2009 disavowing the notion that Chinese FDI was in any way politically motivated or controlled (Zhang, 2009).

In response, the Australian Government has consistently rejected that its policy is nationalistic in orientation or application (see Crean, 2009; Swan, 2008c). However, these criticisms have refused to go away, and have recently been picked up by academic commentators joining the growing disquiet over perceived regulatory discrimination against Chinese investors (see Drysdale \& Findlay, 2009; Thirlwell, 2008). While occupying the opposite end of the policy debate from those arguing for even further scrutiny of Chinese investments, these groups share an understanding of the post-2008 policy regime as one motivated (if unwisely) by resource nationalistic concerns.

The belief that the recent Australian approach to Chinese foreign investment embodies a move towards resource nationalism appears to have become a consensus view. However, upon closer examination of the evidence this interpretation becomes difficult to sustain. It can be argued that these controls are neither

15 “'Racist' FIRB a handbrake on growth, says miner”, The Age, 30 September 2009.
16 “Chinese win right to lift stake in Rio”, Sydney Morning Herald, 25 October 2008. 
motivated by nor result in resource nationalism, in the sense of being an attempt to take the Australia-China minerals trade 'out of the market' and subject it to political control. Rather, they appear to be little more than defensive regulations, aimed at neutralising potential non-commercial behaviour by Chinese stateowned investors. By considering the political-economic context from which Chinese mining investment in Australia has originated, the principles enumerated in the policy declaration of February 2008, and their subsequent application in specific cases, a clearer picture emerges which demonstrates that Australia's approach more closely aligns with a liberal rather than nationalistic approach to natural resource management.

\section{The characteristics of Chinese FDI in foreign mining projects}

As an analysis of the Australian management of Chinese FDI inflows needs to place policy in the context to which it responds, it is important to begin with an understanding of the nature of the investments which are being increasingly scrutinised. Recent Chinese FDI into the Australian mining industry is qualitatively unlike investment from other sources in a variety of ways. First, it is driven primarily by demand from the Chinese steel industry for raw materials, and thus is concentrated in just two mining sectors - iron ore and coking coal. Second, these investments have largely been made by SOEs rather than private firms, typically either mining groups or steel mills themselves, and usually with some kind of governmental financial assistance. Third, they arguably originate from a state-backed agenda that aims to use FDI to influence transactions in international iron ore and coking coal markets. An examination of the political-economic context of the Chinese steel industry, and its recent patterns of mineral-seeking FDI, will highlight the origins and nature of these features of Sino-Australian minerals investment.

Like many Chinese industries, the origin of its contemporary steel industry dates back to Deng's 1978 reforms, which promoted the gradual replacement of command administration with a 'planned market economy’ (Minami, 1994). However, unlike most industries which were subject to a processes of gradual marketisation and privatisation (Naughton, 1995, 2006), given its role as a supplier of a critical industrial input steel was considered a strategic sector (Xin \& Findlay, 1985), and the state opted to maintain control via ownership and planning mechanisms. Privatisation of the industry was explicitly ruled out (Movshuk, 
2005), and significant state subsidies were extended to promote the expansion and modernisation of steelworks ${ }^{17}$. While management autonomy was devolved from the state to enterprises under a 'modern enterprise system' in 1993, state oversight was retained by requirements demanding the placement of Communist Party officials in all top management positions (Bai \& Bennington, 2003, 2007; Hassard et al., 1999). State control of the industry was further cemented by rationalisation plans that aimed to create a small group of 'national champions' through the state-mandated merger of steel enterprises, first undertaken in 1997 (Sutherland, 2001), and again in 2005 (NDRC, 2005).

The effects of these policies have been two-fold. First, the industry expanded at an extremely rapid place, with China rising from being an insignificant player in steel (producing 46 million tonnes in the early 1990s (China Steel Yearbook, 2007)), to a position of global dominance, producing 500 million tonnes and accounting for some 37\% of global production in 2008 (IISI, 2009: 8). The second has been to base this rapid growth on a group of large-scale, technically modern 'key enterprises' accounting for around $80 \%$ of national steel production ${ }^{18}$. This group is in turn dominated by a core group of six steel enterprises with annual production over 20 million tonnes ${ }^{19}$, of which five are predominantly state-owned (Price et al., 2007a, 2007b). Recent policies announced in 2009, which restrict the growth of small private steel mills and offer financial support to encourage buyouts by the core firms, are expected to further strengthen the state-ownership of the industry ${ }^{20}$.

However, as a result of its evident success in increasing output, the Chinese steel industry since the mid2000s had faced increasing difficulties in securing supplies of steelmaking raw materials. China was selfsufficient in the supply of iron ore and coking coal in the 1980s (Sugimoto, 1993), but during the 1990s its steel industry outgrew available domestic reserves of iron ore, leading to a climbing import dependency

\footnotetext{
${ }^{17}$ Disagreement exists over the extent of these subsidies. Official Chinese data presented during its WTO accession package claim these were equivalent to USD 355 million per annum during the 1990s (WTO, 2001: Annex 5B) while US industry sources present evidence suggesting they ran as high as USD 5.2 billion (Price et al., 2007b).

18 “Top 6 crude Chinese steel producers in 2008”, Steel Guru, 16 February 2009.

${ }^{19}$ In order of decreasing size: Baosteel, Hebei I\&S, Wuhan I\&S, Ansteel, Jiangsu Shagang and Jinan I\&S. Only Jiangsu Shagang is privately owned.

20 'China to facilitate steel mergers by policy support', Steel Guru, 20 February 2009; 'China's steel industry benefits from stimulus, support plan', Xinhua, 22 January 2009.
} 
ratio around $70 \%$ today $^{21}$. Its more abundant coal reserves served domestic needs somewhat longer, but owing to competition from other domestic users in the electricity and construction industries, steelmakers were also forced to begin coking coal importation for the first time in $2009^{22}$. Thus, while the steel industry itself remained under state ownership, the production of raw materials for steelmaking increasingly relies on foreign sources of supply, which fall outside the domain of Chinese state control.

Difficulties associated with iron ore importation were further exacerbated by the structure of international iron ore and coking coal markets. Prior to 2005, international trade in these minerals was conducted under long-term contracts, of ten to fifteen years duration, made between steel mills and mining companies. The price of minerals under these contracts was historically determined by annual closed-door negotiations between two informal cartels with relatively equal bargaining power - a Japanese steel mill buyers' cartel, and producers' cartel comprised of the 'Big 3' mining MNCs - Australia's BHP and Rio Tinto, and Brazil's CVRD (Sukagawa, 2010). However, the involvement of Chinese buyers in the negotiation process carried the effect of weakening the bargaining power of Japanese firms on the buyers' side, delivering the Big 3 miners a whip hand to push for rapid price increases in the context of booming Chinese demand. As a result, prices for internationally traded iron ore and coking coal started to boom, with iron ore alone increasing four-fold in six years between 2004 and 2008 (see UNCTAD, 2008). This has placed a massive cost strain on Chinese steel mills, the majority of which have made heavy losses in recent years ${ }^{23}$.

It is in this context that the recent wave of state-led minerals investment from China has occurred. Spurred into action by a $71.5 \%$ increase in the price of iron ore in 2005 considered catastrophic by the industry ${ }^{24}$, the Chinese Government issued a Steel Industry Development Policy in the middle of the year that included various elements to support the industry in the face of new cost pressures (see NDRC, 2005). Central amongst its policies was a state commitment to offer financial support to steel firms to facilitate the

21 “Chinese dependence on imported iron ore hits 70pct”, Steel Guru. 22 March 2010.

22 "Coking Coal Shortage in China to Spur Demand Fight With Japan”, Bloomberg News, 18 December 2009.

23 “Price Hike Exposes Woes of China's Steel Industry”, Caijing Magazine, 18 April 2005; '60\% of Chinese steelmakers to suffer losses by October', Steel Guru, 2 November 2008.

24 “Price Hike Exposes Woes of China's Steel Industry”, Caijing Magazine, 18 April 2005. 
development of foreign mining projects, either wholly-owned or as joint-ventures with foreign partners. Such financial support for the steel industry's outward investment program was soon forthcoming in the form of loan financing ${ }^{25}$, coming from two state-owned policy banks (the China EXIM Bank and China Development Bank) who provide 'policy-finance' on concessional rates (Bonin \& Huang, 2001; Wong \& Chan, 2003); and four state owned-commercial banks (SCBs) whose purpose is to finance SOE activities in line with state-mandated industrial plans (Cousin, 2007; Podpiera, 2006). In 2008, this program was extended by a state directive that instructed non-steel SOEs (such as sovereign wealth funds and mining companies) to assist the program by making foreign mining investments as well, which was again accompanied by a commitment that state financing would be made available ${ }^{26}$.

Given a ready access to state-financing, the results of this foreign investment program have been dramatic, and are summarised in Appendix A. Between 2002 and June 2010, Chinese firms have made forty-eight investments in foreign iron ore and coking coal related-projects, and of those for which data is publicly available, their cumulative value is AUD 38 billion. Thirty-six of the projects, with a value of AUD 27 billion, are located in Australia. In terms of the ownership and financing, forty-two were made by SOEs and were financed by either policy or state-owned banks; and of the six private investments a further two relied on some kind of concessional state financial support. These numbers may still expand, as there are reportedly a further 100 Chinese companies presently conducting mineral exploration in Australia ${ }^{27}$. These projects cover the bulk of Chinese investment in the Australian minerals industry to date, and as of early 2010 six of the invested projects were exporting to $\mathrm{China}^{28}$, with the rest planning to become operational by 2012.

Several goals motivate this ongoing program of state-backed foreign investment. The first, emphasised in the text of the 2005 Steel Policy, is a simple intention to increase the global supply of needed raw materials by providing finance for new mine development. However, analysis of the investments made under the

\footnotetext{
${ }^{25}$ A complete list of financing sources for Chinese FDI in foreign iron ore and coking coal projects is included in Appendix A.

26 "China bides time on Rio stake increase”, Sydney Morning Herald, 11 December 2008.

27 "China beats foreign investment curbs with prospecting”, The Australian, 22 October 2009.

${ }^{28}$ Fortescue Metals, Jimblebar, BaoHI, Jack Hills, Mt Gibson, and Rio Tinto.
} 
program suggests an additional two motivations, of a 'strategic' and 'non-market' nature, are at play. One strategic motivation has been the stated intention to use such investments to develop 'captive mines' under Chinese control, with the intention of diluting the bargaining strength of the Big 3 miners in annual price negotiations. For example, describing its 2009 investment in Australia's Aquila Resources, the Chairman of Baosteel claimed: "[The Aquila investment] will strengthen Baosteel's control over strategic resources, weaken the monopolistic grip over global iron ore supplies and lower purchasing costs "29; and an attempted Chinalco investment in Rio Tinto in 2009 was publicly rationalised on the same grounds ${ }^{30}$. The connection between strategic investments and bargaining power in international minerals markets is also highlighted by the fact that the Chinese government has publicly blamed recent price rises on the "monopoly status" of the Big 3 miners"31; and the 2005 Steel Policy itself also detailed related plans for the formation of a cartel amongst Chinese iron ore buyers to resist price increases ${ }^{32}$.

A second strategic goal is also evident in the practice of supply contracting with joint ventures, where the Chinese party has made investment conditional on acquiring long-term contracts for the bulk of a project's output. While long-term contracts with Chinese steel mills have been signed by most projects in which a Chinese partner has invested, in eleven cases contracts have covered the entirety of planned output, despite the Chinese partner taking only a minority stake in ownership (see Appendix A). In a handful of other cases, investments have also been made conditional on special pricing agreements, whereby minerals would be supplied to the Chinese partner at discounts to the prevailing world benchmark price ${ }^{33}$.

These practices evidence that the strategic goals of increasing the market power of Chinese firms in international price negotiations with major mining companies, and securing lower-cost mineral supply

\footnotetext{
29 “Baosteel confirms paying provisional ore prices”, Reuters, 31 August 2009.

30 "China sees iron ore edge after Rio Tinto stake purchase”, Sydney Morning Herald, 13 February 2009. This investment ultimately failed, though for commercial reasons unrelated to Australian FDI screening.

31 “Confusion reigns over China's iron ore policy”, Steel Business Briefing, 16 March 2006.

${ }^{32}$ Described benignly in the plan as "industry co-operation" (NDRC, 2005); but somewhat more aggressively by CISA as "restoring order" to iron ore markets ('Steel sector gets booster package', China Daily, 15 January 2009).

${ }^{33}$ Evident in sales agreements made with Chinese investors by Fortescue Metals Group and Mt Gibson: "Fortescue deal with China puts pressure on big miners", Sydney Morning Herald, 17 August 2009; "Mt Gibson forced to sell ore at 60\% discount”, Sydney Morning Herald, 3 November 2008.
} 
independent of them, and has loomed large in the recent wave of Chinese FDI. Such strategic priorities arguably dilute normal commercial goals - particularly profit considerations - in the execution of these investment, and demonstrate a clear intention to use FDI to shift China's mineral imports out of existing international market structures. Given that all outward Chinese FDI by SOEs requires the prior approval of both the National Development and Reform Commission and the Chinese Cabinet (OECD, 2008; Wu, 2005), and in the case of steelmaking raw materials has consistently been funded by state-owned banks with a policy-orientation, it would appear that this strategic agenda has at least the imprimatur if not active support of the Chinese government.

It is this wave of foreign investment, and its specific state-backed and strategic characteristics, which provides the context of Australia's recent changes in policy regarding Chinese FDI. This context is crucial in explaining the nature of Australian regulatory response, an analysis shows that it is this Chinese program, and its potential to shift the Sino-Australian trade in steelmaking raw materials out of existing international market structures and subject it to a degree of control by strategically-oriented Chinese SOEs, to which the Australian response has primarily been oriented.

\section{Examining the Australian response}

The regulation of these Chinese investments has posed a number of dilemmas for the Australian Government. While FDI is generally welcomed in Australia, and the recent round of Chinese minerals investment helped Australia escape the worst of the global financial crisis of 2008-09, their state-led and strategic nature have nonetheless given cause for a number of concerns. A first concerns the priorities of the Chinese investors, and whether they are motivated to invest in ways that supports the development of the Australian mining industry (namely, expanding output and employment), or would try to serve the Chinese Government's goals for its steel industry (through preferentially supplying customers at discounted prices). A second relates to the issue of behaviour, and whether by virtue of their state-ownership these firms would act in a commercial manner, or would instead use ready access to Chinese state finance to increase the supply of minerals to China with minimal concern for the profitability of projects. A third concern, that bears upon the degree to which the former two might be actualised, is the issue of control - 
whether the Chinese firms would move to control the operation of firms they invested in, or whether they would participate as minority partners and leave control with the majority (non-Chinese) owners.

These concerns all relate to whether the minerals trade between Australia and China would remain 'in the market', or would influence this trade to serve Chinese state-mandated priorities. The state-led and strategic nature of the investments made thus far at least suggests that such a risk exists. Importantly, a close examination of Australian regulatory scrutiny of Chinese mineral investments post-2008 shows that it is precisely these concerns that catalysed the Australian Government's initial change in approach, and has since informed how foreign investment screening rules have been applied.

At the level of formal controls, the concern that Chinese investment might shift Australia's minerals trade with China 'out of the market' appears to be the motivating feature behind the updated FDI screening guidelines issued in February 2008. The bulk of the guidelines largely restated the content of the FDI regime in place since $1979^{34}$, where investments in either (a) sensitive industries; (b) those undertaken by foreign government entities; or (c) over various size thresholds would be screened by the FIRB according to 'national interest' criteria, and referred to the Treasurer for approval or rejection. The only new information included in the 2008 guidelines was a clarification of six specific criteria that would be applied in the case of investment from foreign government entities (Department of Treasury (Aust.), 2008). These included whether:

\footnotetext{
${ }^{34}$ As per the Foreign Acquisitions and Takeovers Act (Cth) 1979.
} 
1. The investor's operations are independent of the relevant foreign government;

2. The investor is subject to and adheres to the law, and observes common standards of business behaviour;

3. The investment hinders competition, or leads to undue concentration or control in an industry;

4. The investment impacts on Australian government revenue or other policies;

5. The investment impacts on national security; and

6. The investment impacts on the operation or direction of an Australia business, including its contribution to the economy and wider community.

A concern with the economic consequences of 'strategic' investments is plainly evident, particularly in the first three criteria that address issues of whether an SOE is independent of its government, whether it behaves in a manner like other private businesses, and the degree to which it would acquire market power over local firms. That these criteria would be applied to Chinese SOEs in order to ensure 'marketconforming' rather than strategic behaviour manner was reinforced by the Treasurer in a speech to the Chinese Communist Party in June 2009, where it was explained that "Like China, Australia screens foreign investment... we want to ensure that investment is consistent with our aim of maintaining a system in which investment and sales decisions are driven by market forces rather than external strategic or political considerations" (Swan, 2008a). Furthermore, in mid-2009 the FIRB indicated it was pursuing this aim of ensuring market-conforming behaviour through an informal " $15 / 50$ guideline". Under this system, investments would be considered appropriate if below certain thresholds at which the risk of strategic behaviour was deemed to become acute, set at 15\% ownership of an existing firm or $50 \%$ of a new project $^{35}$

These statements indicate the primary Australian concern with Chinese investment lay with the potential for non-market behaviour owing to their state-directed nature, with screening intended to prevent such behaviour occurring. Of course, this only demonstrates a stated commitment to scrutinise investments on

35 “Keep Stake at 15\%: FIRB”, Sydney Morning Herald, 25 September 2009. 
these grounds, and it could be suggested that other (more nationalistic) motives may also be present. However, the manner in which this commitment has been applied through various regulatory decisions confirms that the policy has largely been confined to defensively attempting to neutralise the potential for non-market behaviour by Chinese firms, rather than any effort to restrict their entry into the Australian mining industry more broadly.

The first dimension of this analysis concerns the Chinese mining FDI approvals made since February 2008, which have consistently been quite liberal. Twenty-three Chinese applications have been approved (compared to only four rejections), and every proposal which fell under the FIRB's 15/50 guidelines was allowed as proposed. Indeed, the guideline itself has been rather flexibly applied, with three investments over the $15 \%$ rule and five over the $50 \%$ rule approved ${ }^{36}$; usually in situations where the rejection would result in the failure of a project entirely, such as in the case of China Minmetals' acquisition of the bankrupt Oz Minerals in 2009. Here, it is clear that in cases where Chinese SOEs do not acquire ownership shares large enough to influence firm behaviour, approval has been unproblematic; and that in cases of economic necessity even larger acquisitions have been allowed.

A consideration of rejected applications tells a similar story. Of the four rejections issued by the Treasurer, two (SOE investments in $\mathrm{Oz}$ Minerals and the Hawks Nest project ${ }^{37}$ ) were rejected for security reasons relating to the proximity of mines to remote defence facilities; and in the case of Oz Minerals approval was subsequently given when the sensitive mine was removed from the deal (Swan, 2009a, 2009c). These decisions are arguably the result of extraneous security factors unrelated to the FDI regime itself. In the other two cases, the rejected applicants were asked to resubmit applications below a 50\% ownership level due to concerns that they would result in excessive Chinese control of the highly concentrated rare earth minerals sector (Lynas Metals ${ }^{38}$ ) and the newly developing Midwest iron ore region (Murchison Metals)

\footnotetext{
${ }^{36}$ Specifically: Grange Resources, Felix Resources and Oz Minerals (over 15\% of existing firms); and Midwest, Cape Lambert, SinoIron, Macarthur Coal and Extension Hill (over 50\% of new projects). See Appendix A for details.

37 "Chinese blocked from Woomera mining venture", ABC Online, 24 September 2009.

38 "As Commodity Prices Rebound, Australia Limits Foreign Investors", Wall Street Journal, 28 September 2009.
} 
respectively. The latter was subsequently approved when the Chinese investor agreed to this request (Swan, 2008e). However, rather than constituting rejections outright, these decisions only show a desire to maintain majority non-Chinese control in cases where there is a high risk that strategic behaviour might affect the mining industry more broadly; and in the context of the far greater number of approvals granted would appear to be competition-related exceptions to an otherwise open regime.

Perhaps more significant than rejections has been the use of conditionality in approving Chinese investments. In cases where a proposed investment has raised the potential for the use of market power over other industry participants, the Australian Government has made approval conditional on legally binding commitments that the firm will behave in a market-conforming manner. This has occurred in five cases, and examples include commitments to: market output on an 'arm's length' basis (Valin-FMG (Swan, 2009b) and Minmetals-Oz Minerals (Swan, 2009c)); not to seek a director's position in the target firm (Chinalco-Rio Tinto (Swan, 2008d)); to support local infrastructure providers (Ansteel-Gindalbie (Swan, 2009d)); and to publicly-list and subsequently float a portion of the company to ensure operations are subject to shareholder scrutiny (Yanzhou-Felix ${ }^{39}$ ). While small in number, such conditional approval has occurred in all of the largest investments, covering some AUD 21 billion of the 26 billion total approvals in iron ore and coking coal. In each case the Chinese firm has complied, if after a somewhat lengthy negotiation process. As these conditions have legal force, any subsequent breach would in principle allow the Treasurer to order the Chinese partner to divest its holding; though this contingency is yet to eventuate. Nonetheless, this conditionality highlights a novel use of FDI screening by the Australian Government, where rather than rejecting problematic applications, a bargaining process is undertaken to extract behavioural conditions to neutralise the risks associated with state-ownership and strategic behaviour. Indeed, had rejection instead been used in these high-risk cases, Chinese FDI in the Australian iron ore and coking coal sectors would, ceteris paribus, be only a fifth the level that ultimately was allowed.

\footnotetext{
39 “China set for \$3.5bn takeover”, The Australian, 24 October 2009.
} 


\section{Understanding the Australian response}

Regardless the reception given to it by both commentators and the involved parties, what does this analysis reveal regarding Australia's post-2008 control of Chinese FDI in its minerals industry? By considering the characteristics of the investments targeted for regulation, the content of Australian policy, and the method in which it has been applied, a more informed understanding of its motivations and implementation becomes apparent.

Firstly, it is clear what the policy is not. Contrary to the claims of both detractors and supporters of the policy, it is demonstrably evident that these controls are not motivated by nor result in any degree of resource nationalism. First, there is no evidence of the use of FDI controls to leverage a greater share of 'Australian' ownership of the minerals industry. The 2008 policy contains no intention to achieve 'national' ownership of mining projects; lacks any rules by which it could be enforced; and the manner in which it has been applied has not resulted in any maximisation of 'Australian' ownership specifically. Second, neither is there any evidence of a negative targeting of Chinese investors on the basis of nationality. Chinese applications have in the main have been approved; and the minority cases where rejection has occurred are accounted for by extraneous factors relating to security and competition concerns. The intervention in market processes through FDI controls to prioritise national over foreign investors - a defining characteristic of resource nationalism - is simply not evident. The characterisation of Australia's post-2008 approach to Chinese investment as an instance of rising resource nationalism may well be a useful political device, used by both sides in the current debate to build support or opposition to the post-2008 regime. However, and regardless of their utility as political devices, as arguments over the nature of the Australian FDI regime such claims lack sustaining evidence.

Second, and perhaps more importantly, this analysis suggests the conclusion that Australia's regulation of Chinese FDI in fact embodies an avowedly liberal approach. The intention to place international patterns of minerals trade and investment squarely 'in the market' - an inherently liberal commitment - appears as the central concern both of the policy announced in 2008, and the forms in which it has been subsequently applied. Investment proposals, which by virtue of their content and context do not pose a risk of non- 
market behaviour, have been consistently approved - even in cases when made by a Chinese SOE and/or appear to be motivated by strategic goals. Only when a proposal carries a meaningful risk of state-backed strategic behaviour has FIRB screening been used with any consequence. Even then, outright rejection has been eschewed in favour of behavioural conditions that mandate relevant commitments to ensure marketbased commercial behaviour by investors but go no further. Additionally, such behavioural conditionality does not appear to have deterred Chinese investors, with Australia enjoying large inflows in iron ore and coking coal, and clearly remaining China's preferred FDI host internationally, since 2008. Thus, the political control of Chinese FDI by the Australian government appears as at most a defensive tactic, employed to strike a balance between the benefits of FDI and risks of strategic behaviour associated with foreign governmental ownership and backing. That the primary criterion informing such a balancing is a desire for market-oriented behaviour, and that attempts at control have gone no further, highlights the inherently liberal rather than nationalistic character of the Australian Government's approach.

The paradoxical nature of this conclusion - that FDI controls can be used as a liberal rather than nationalistic policy - is worth noting. FDI controls are by their nature an intervention into (normally) market-based international economic processes; and their historical role in the policy armoury of resource nationalism further reinforces a seemingly illiberal nature. However, in the case of recent Australian experience the reverse appears true - where the limited and discretionary use of FDI controls has in both aim and execution sought to keep the Australia-China minerals trade firmly within the market. Contrary to expectations, national control and scrutiny of FDI inflow can act as a liberal approach to resources management, when deployed as strategy to mitigate state interventions into market processes emanating from abroad. An important corollary is that state intervention in foreign economic flows is not necessarily illiberal, nor must a liberal policy necessarily be laissez-faire in nature. The liberality of economic policy must be measured not by the degree to which state involvement is present, but by the yardstick of the context in which it is executed and issues to which it responds. 
Conclusion

Claims of resource nationalism in recent Australian policy towards Chinese FDI in its mining industry fail to properly understand its context, goals or application. Despite a seeming consensus forming around this belief among both Australian and Chinese participants in debates over this policy, if resource nationalism is understood as an attempt to take trade and investment in minerals out of the international market, there is little evidence this is going on. Rather, it would appear that Australia's intention has been to selectively and defensively regulate investment by Chinese SOEs in order to ensure its trade with China remains firmly in the market - an inherently liberal commitment. In the application of FDI controls it has consistently pursued this goal but gone no further; and as long of Chinese SOEs are willing to behave in a marketoriented manner, Australia's FDI regime provides them an open investment climate in which to seek minerals supply for the Chinese steel industry. While claims to the contrary may be made by the affected parties, a characterisation of Australia's policy as inherently liberal provides a better explanation of the outlook and application of contemporary Australian policy towards Chinese investment. 
Appendix A: Chinese investments in foreign iron ore and coking coal projects, 2002-2010

\begin{tabular}{|c|c|c|c|c|c|c|}
\hline Firm & Project & Date & $\begin{array}{l}\text { Equity } \\
\text { acquired }\end{array}$ & $\begin{array}{l}\text { Source of } \\
\text { financing }\end{array}$ & $\begin{array}{l}\text { Size (mtpa) and } \\
\text { contracts ( } \% \text { of } \\
\text { output) }\end{array}$ & Value* \\
\hline \multicolumn{7}{|c|}{ In Australia } \\
\hline Baosteel & BaoHI (IO) & 2002 & $46 \%$ & SCB & $7.0(100 \%)$ & NA \\
\hline Yanzhou Mining & Austar (CC) & 2004 & $100 \%$ & $\mathrm{SCB}$ & $2.0(100 \%)$ & 31 \\
\hline Tangshan & & & & $\mathrm{SCB}$ & & NA \\
\hline Wugang & & & & SCB & & NA \\
\hline Magang & Jimblebar (IO) & 2004 & $40 \%$ & PB & $12.0(100 \%)$ & NA \\
\hline Jiangsu Shagang & & & & $\begin{array}{c}\text { Private, } \\
\text { state grant }\end{array}$ & & NA \\
\hline SOE Consortium & Yilgarn Resources & $2007-08$ & $50 \%$ & PB & Infrastructure & 250 \\
\hline CITIC Pacific & Macarthur (CC) & 2007-09 & $20 \%$ & SWF & None & 1000 \\
\hline Rockcheck & Aurox (IO) & $2007-08$ & $12 \%$ & SCB & Plan $6.0(100 \%)$ & 15 \\
\hline Ansteel & Gindalbie (IO) & 2007-09 & $36 \%$ & SCB & None & 200 \\
\hline Ansteel & Karara (IO) & 2007 & $50 \%$ & $\mathrm{~PB}$ & Plan $10.0(100 \%)$ & 530 \\
\hline Tonghua I\&S & Cairn Hill (IO) & $2007-10$ & $10 \%$ & $\mathrm{SCB}$ & Plan $7.0(100 \%)$ & 14 \\
\hline Sinosteel & Midwest (IO) & 2008 & $100 \%$ & $\mathrm{~PB}$ & Plan $15.0(100 \%)$ & 1400 \\
\hline Sinosteel & Murchison (IO) & 2008-09 & $5.8 \%$ & PB & None & 15 \\
\hline Wugang & Eyre Iron (IO) & 2008 & $60 \%$ & PB & Plan $10.0(80 \%)$ & 260 \\
\hline Wugang & Centrex (IO) & 2008 & $15 \%$ & PB & NA & 10 \\
\hline Shougang & Balmoral South (IO) & 2008 & $18 \%$ & PB & Plan $12.0(100 \%)$ & 58 \\
\hline Jiangsu Shagang & Grange (IO) & 2008 & $45 \%$ & $\begin{array}{c}\text { Private, } \\
\text { state grant }\end{array}$ & $2.5(100 \%)$ & NA \\
\hline Shougang & Mt Gibson (IO) & 2008 & $40 \%$ & SCB & Plan $10.0(60 \%)$ & NA \\
\hline CMG & Cape Lambert (IO) & 2008 & $100 \%$ & SCB & None & 400 \\
\hline Hunan Valin & Golden West (IO) & 2008 & $11 \%$ & SCB & Plan $10.0(45 \%)$ & 27 \\
\hline CITIC Pacific & SinoIron (IO) & 2008 & $100 \%$ & SWF & Plan $27.6(100 \%)$ & 560 \\
\hline Xinwen Mining & $\begin{array}{l}\text { Coal Exploration } \\
\text { Permits }\end{array}$ & 2008 & $100 \%$ & $\mathrm{SCB}$ & None & 1500 \\
\hline $\begin{array}{l}\text { China Western } \\
\text { Mining }\end{array}$ & FerrAus (IO) & 2008 & $10 \%$ & $\mathrm{SCB}$ & $\begin{array}{l}\text { Development } \\
\quad(100 \%)\end{array}$ & 21 \\
\hline Chinalco & Rio Tinto (IO \& CC) & 2008 & $9 \%$ & $\mathrm{SCB}$ & NA & 15500 \\
\hline Hunan Valin & $\begin{array}{l}\text { Fortescue Metals } \\
\text { (IO) }\end{array}$ & 2009 & $15 \%$ & SWF & Plan $50.0(100 \%)$ & 1200 \\
\hline Baotou & Bungalow (IO) & 2009 & $50 \%$ & $\mathrm{SCB}$ & Plan $3.0(33 \%)$ & 40 \\
\hline $\begin{array}{l}\text { China } \\
\text { Metallurgical } \\
\text { Investment Co. }\end{array}$ & Beyondie (IO) & 2009 & $50 \%$ & $\mathrm{SCB}$ & Plan 3.0 & 200 \\
\hline Yanzhou Mining & $\begin{array}{l}\text { Felix Resources } \\
\text { (CC) }\end{array}$ & 2009 & $100 \%$ & $\mathrm{SCB}$ & $5.0(100 \%)$ & 3500 \\
\hline $\begin{array}{l}\text { Chongqing } \\
\text { Minerals Dev. }\end{array}$ & Extension Hill (IO) & 2009 & $60 \%$ & Local Govt & Plan $10.0(100 \%)$ & NA \\
\hline $\begin{array}{l}\text { China Railway } \\
\text { Material Corp. }\end{array}$ & FerrAus (IO) & 2009 & $12 \%$ & $\mathrm{SCB}$ & $\begin{array}{l}\text { Development } \\
\quad(100 \%)\end{array}$ & 13 \\
\hline Jinchuan Group & Fox Resources (IO) & 2009 & $11 \%$ & $\mathrm{SCB}$ & None & 18 \\
\hline Baosteel & Aquila (IO) & 2009 & $15 \%$ & $\mathrm{SCB}$ & $\begin{array}{l}\text { Development } \\
\quad(>50 \%)\end{array}$ & 240 \\
\hline Sichuan Taifeng & IMX (IO) & 2010 & $20 \%$ & Private & None & 47 \\
\hline Huaxi & Lincoln (IO) & 2010 & $13 \%$ & Private & Development (50\%) & 8 \\
\hline
\end{tabular}




\begin{tabular}{|c|c|c|c|c|c|c|}
\hline Shenhua & Centennial (CC) & 2010 & $10 \%$ & $\mathrm{SCB}$ & None & 200 \\
\hline \multicolumn{7}{|c|}{ In Other Countries } \\
\hline Baosteel & $\begin{array}{l}\text { Baovale (IO) } \\
\text { (Brazil) }\end{array}$ & 2002 & $50 \%$ & SCB & $8.0(100 \%)$ & 38 \\
\hline CNMIEC & $\begin{array}{l}\text { Belinga (IO) } \\
\text { (Gabon) }\end{array}$ & 2008 & $85 \%$ & SCB & Development & 955 \\
\hline Shunde Rixin & $\begin{array}{l}\text { Unnamed (IO) } \\
\text { (Chile) }\end{array}$ & 2009 & $70 \%$ & Private & Development & NA \\
\hline Wugang & $\begin{array}{l}\text { Consolidated } \\
\text { Thompson (IO) } \\
\text { (Canada) }\end{array}$ & 2009 & $25 \%$ & $\mathrm{~PB}$ & $8.0(50 \%)$ & 360 \\
\hline $\begin{array}{l}\text { China Investment } \\
\text { Corp }\end{array}$ & $\begin{array}{l}\text { Teck Resources } \\
\text { (CC) (Canada) }\end{array}$ & 2009 & $17 \%$ & SWF & None & 1875 \\
\hline Wugang & MMX (IO) (Brazil) & 2009 & $21.5 \%$ & SCB & $40.0(50 \%)$ & 435 \\
\hline $\begin{array}{l}\text { China Railway } \\
\text { Materials } \\
\text { Commercial Corp }\end{array}$ & $\begin{array}{l}\text { Africa Minerals (IO) } \\
\text { (Sierra Leone) }\end{array}$ & 2010 & $12.5 \%$ & SCB & $8.0(100 \%)$ & 275 \\
\hline CIF & Kaila (IO) (Brazil) & 2010 & NA & Private & $\begin{array}{c}\text { Development } \\
\quad(100 \%)\end{array}$ & 2914 \\
\hline ECE & $\begin{array}{l}\text { Itaminas (IO) } \\
\text { (Brazil) }\end{array}$ & 2010 & $100 \%$ & $\begin{array}{l}\text { Provincial } \\
\text { Govt }\end{array}$ & $3.0(100 \%)$ & 1316 \\
\hline Wugang & Bong (IO) (Liberia) & 2010 & $60 \%$ & $\mathrm{SCB}$ & None & 75 \\
\hline Chinalco & $\begin{array}{l}\text { Simandou (IO) } \\
\text { (Guinea) }\end{array}$ & 2010 & $45 \%$ & SCB & None & 1481 \\
\hline Wugang & $\begin{array}{l}\text { Zambeze (IO) } \\
\text { (Mozambique) }\end{array}$ & 2010 & $40 \%$ & SCB & Development (40\%) & 950 \\
\hline \multicolumn{2}{|c|}{ Subtotal to Australia } & & & & \multicolumn{2}{|l|}{$27257(72 \%)$} \\
\hline \multicolumn{2}{|l|}{ Subtotal to Others } & & & & \multicolumn{2}{|l|}{$10674(28 \%)$} \\
\hline \multicolumn{2}{|l|}{ Total } & & & & \multicolumn{2}{|l|}{37931} \\
\hline
\end{tabular}

\# SCB refers to 'state-owned commercial bank'; SWF to 'sovereign wealth fund'; and PB to two 'policy banks' (the China Development Bank and China Export-Import Bank).

* For comparison, investment values are converted to AUD millions at then-current exchange rates with reported currency.

Source: Author's compilation from: ABC Online 12/04/2010; ABN Newswire 14/01/2009; American Metals Market 21/12/2001; The Australian 12/11/2004, 17/06/2008, 27/06/2008, 13/08/2008, 25/08/2008, 06/092008, 12/09/2008, 23/10/2008, 21/11/2008, 18/12/2008, 19/12/2008, 10/01/2009, 06/07/2009, 24/10/2009, 23/12/2009; (Australasian Resources, 2007); Bloomberg 25/03/2009, 13/08/2009, 30/11/2009; Caijing 15/05/2008, 07/07/2008, 14/08/2008; (Centrex Metals, 2010); China Daily 09/07/2008, 01/04/2009; (CITIC Pacific Mining, 2010); Financial Times 01/03/2004, 30/04/2008; (IMX Resources, 2007); Mineweb 24/05/2010; Mining Weekly 27/02/2009; Price et al., 2007a, 2007b); Reuters 23/10/2008, 08/09/2009, 06/01/2010; (Rio Tinto, 2001, 2009); (Sinosteel Midwest, 2010); Steel Business Briefing 10/11/2009; Steel Guru 10/12/2008, 05/03/2009, 16/03/2010, 10/04/2010, 25/06/2010; Sydney Morning Herald 15/07/2008, 03/09/2008, 20/02/2009, 25/02/2009, 04/03/2009, 28/08/2009, 25/09/2009, 15/02/2010; WA Business News 03/07/2009; Wall Street Journal 30/12/2009, 26/03/2010; (Yilgarn Infrastructure, 2009). 
Bibliography

Argus, D. (2009). Being Lucky is Not Enough - Address to the Melbourne Mining Club, 22 October 2009. Retrieved 25 November 2009, from http://www.melbourneminingclub.com/attachments/0000/0050/Don_Argus.mp3

Arndt, H. W. (1974). Resources Diplomacy, Australia-Japan Economic Relations Research Project Research Paper. Canberra: Australian National University.

Australasian Resources. (2007). "Shougang Team Successfully Completes Australian Based Review of Balmoral South Iron Ore Project in WA", ASX Announcement 27 September 2007, ASX Company Announcements: ASX Ltd.

Bai, X., \& Bennington, L. (2003). Steering and Rowing in Chinese SOEs: the Modern Enterprise System in China Paper presented at the 15th Annual Conference of the Association for Chinese Economics Studies Australia. Retrieved 31 March 2010 from http://mams.rmit.edu.au/h32yzo8tuewj.pdf

Bai, X., \& Bennington, L. (2007). Modern enterprise system and the role of the party and government in Chinese SOEs. International Journal of Business and Systems Management, 1(3), 354-366.

Bochkarev, D., \& Austin, G. (2007). Energy Sovereignty and Security: Restoring Confidence in a Cooperative International System, EastWest Institute Policy Papers (No. 1/2007). New York: EastWest Institute.

Bonin, J. P., \& Huang, Y. (2001). Dealing with the Bad Loans of the Chinese Banks. William Davidson Institute Working Papers Series, Working Paper No. 357.

Bremmer, I., \& Johnston, R. (2009). The Rise and Fall of Resource Nationalism. Survival, 51(2), 149-158.

Centrex Metals. (2010). China Steel Major Pays A $\$ 102$ million in to Centrex and South Australian Iron Ore Joint Venture - Media Release, 7 July 2010. Adelaide: Centrex Metals Limited.

China Steel Yearbook Editorial Board. (2007). China Steel Yearbook 2007. Beijing: China Steel Development Research Institute.

CITIC Pacific Mining. (2010). The SinoIron Project. Retrieved 17 August, 2010, from http://www.citicpacificmining.com/en/project/sino-iron-project/

Cousin, V. (2007). Banking in China. Houndsmills, Basingstoke: Palgrave Macmillan.

Crean, S. (2009). Transcript of Press Conference, 17 June 2009. Retrieved 13 October, 2009, from http://www.trademinister.gov.au/transcripts/2009/090617_pressconf.html

Department of Foreign Affairs and Trade (Aust.). (2009). Australia-China Free Trade Agreement Negotiations. Retrieved 26 March 2009, from http://www.dfat.gov.au/geo/china/fta/

Department of Treasury (Aust.). (2008). Summary of Australia's Foreign Investment Policy. Canberra: Australian Government Publishing Service

Downs, E. S. (2004). The Chinese Energy Security Debate. The China Quarterly, 177, 21-41.

Drysdale, P., \& Findlay, C. (2009). Chinese foreign direct investment in the Australian resource sector. In R. Garnaut, L. Song \& W. T. Woo (Eds.), China's New Place in a World in Crisis (Chpt. 16). Canberra: ANU E-Press.

Filho, C. V. (2002). Main considerations in the formulation of mining policies to attract foreign investment. Applied Earth Science: IMM Transactions B, 111(3), 177-182.

Gilbert, C. L. (1995). International Commodity Control: Retrospect and Prospect, World Bank Policy Research Working Papers (No. WPS 1545). New York: World Bank.

Gilpin, R. (1987). The Political Economy of International Relations. Princeton: Princeton University Press.

Haselip, J., \& Hilson, G. (2005). Winners and losers from industry reforms in the developing world: experiences from the electricity and mining sectors. Resources Policy, 30(2), 87-100.

Hassard, J., Sheehan, J., \& Morris, J. (1999). Enterprise reform in Post-Deng China. International Studies of Management and Organisation, 29(3), 54-83.

Hay, J. (2009). Challenges to liberalism: The case of Australian energy policy. Resources Policy, 34(3), 142-149.

IMX Resources. (2007). IMX Resources Commits to Cairn Hill Development - Press Release, 9 January 2007. Perth: IMX Resources NL.

International Iron and Steel Institute. (2009). World Steel In Figures 2009. Brussels: IISI Committee on Economic Studies. 
Jenkins, B. (1986). Reexamining the "Obsolescing Bargain": A Study of Canada's National Energy Program. International Organisation, 40(1), 139-165.

Kreft, H. (2006). China's Quest for Energy: Resource diplomacy in a global market. Policy Review, 139 (October-November).

Kumar, R. (1990). Public reform to expand mining investment in Sub-Saharan Africa. Resources Policy, 16(4), 242-255.

Maizels, A. (1992). Commodities in Crisis: The Commodity Crisis of the 1980s and the Political Economy of International Commodity Policies. Oxford: Oxford University Press.

Maponga, O., \& Maxwell, P. (2001). The Fall and Rise of African Mining. Minerals \& Energy, 16(3), 927.

Mares, D. R. (2010). Resource Nationalism and Energy Security in Latin America: Implications for Global Oil Supplies, James A. Baker III Institute for Public Policy Working Papers. Houston: Rice University.

Minami, R. (1994). The Economic Development of China: A Comparison with the Japanese Experience. New York: St Martin's Press.

Ministry of Commerce (PRC). (2005). Foreign Market Access Report 2005. Beijing: Ministry of Commerce.

Moran, T. H. (1971). New Deal or Raw Deal in Raw Materials? Foreign Policy, 5, 119-134.

Moran, T. H. (1974). Multinational corporations and the politics of dependence: Copper in Chile. Princeton: Princeton University Press.

Moran, T. H. (1985). Multinational Corporations and the Developing Countries: An Analytical Overview. In T. H. Moran (Ed.), Multinational Corporations: The Political Economy of Foreign Direct Investment (Chpt. 1). Lexington, Mass: Lexington Books.

Moran, T. H. (1992). Mining Companies, Economic Nationalism, and Third World Development in the 1990s. In J. E. Tilton (Ed.), Mineral Wealth and Economic Development. Washington: Resources for the Future.

Movshuk, O. (2005). China's Steel Industry: Recent Reform Initiatives and Their Impact on Enterprise Performance. In H. Lee, E. D. Ramstetter \& O. Movshuk (Eds.), Restructuring of the Steel Industry in Northeast Asia (Chpt. 3). Houndsmills, Basingstoke: Palgrave Macmillan.

National Development and Reform Commission (PRC). (2005). China's Steel Industry Development Policy.

Naughton, B. (1995). Growing Out of the Plan: Chinese Economic Reform, 1978-1993. Cambridge: Cambridge University Press.

Naughton, B. (2006). Top-Down Control: SASAC and the Persistence of State Ownership in China. Paper presented at the China and the World Economy. Retrieved 31 March 2010 from www.nottingham.ac.uk/shared/shared levevents/conferences/2006 June China Naughton.doc

Ohara, Y. (1974). Brazilian Economic Development Since 1956: A Study on the Policies Reflecting the Stages of Growth. The Developing Economies, 12(2), 133-154.

Organisation for Economic Co-operation and Development. (2008). OECD Investment Policy Reviews China 2008: Encouraging Responsible Business Conduct. Paris: Organisation for Economic Cooperation and Development

Owen, A. D. (1988). Australia's role as an energ exporter. Energy Policy, 16(2), 131-151.

Podpiera, R. (2006). Progress in China's Banking Sector Reform: Has Bank Behaviour Changed? IMF Working Papers, WP/06/71.

Price, A. H., Brightbill, T. C., Weld, C. B., \& Nance, D. S. (2007a). Government Ownership and Control of China's "Private” Steel Producers. Washington: Wiley Rein LLP

Price, A. H., Brightbill, T. C., Weld, C. B., \& Nance, D. S. (2007b). Money for Metal: A Detailed Examination of Chinese Government Subsidies to its Steel Industry. Washington: Wiley Rein LLP

Rio Tinto. (2001). Hamersley Iron forges JV with China's Baosteel - Australian Stock Exchange Company Announcement, 21 December 2001. Melbourne: Rio Tinto Limited.

Rio Tinto. (2009). Iron Ore - Key Data. Retrieved 29 April 2009, from http://www.riotinto.com/whatweproduce/572 iron ore 3565.asp

Rodrik, D. (1982). Managing Resource Dependency: The United States and Japan in the Markets for Copper, Iron Ore and Bauxite. World Development, 10(7), 541-560.

Sinosteel Midwest. (2010). Sinosteel Midwest Projects. Retrieved 17 August, 2010, from http://www.sinosteelmidwest.com.au/projects.html 
Sugimoto, T. (1993). The Chinese Steel Industry. Resources Policy, 19(4), 264-286.

Sukagawa, P. (2010). Is iron ore priced as a commodity? Past and current practice. Resources Policy, 35(1), 54-63.

Sutherland, D. (2001). China's Large Enterprises and the Challenge of Late Industrialisation. London and New York: RoutledgeCurzon.

Swan, W. (2008a). "A Modern Relationship with China" - Speech to the Central Party School Communist Party of China, 11 June 2008. Retrieved 24 March, 2010, from http://www.treasurer.gov.au/DisplayDocs.aspx?doc=speeches/2008/019.htm\&pageID=005\&min= wms\&Year $=2008 \&$ DocType $=1$

Swan, W. (2008b). "A Remarkable Place at a Remarkable Time" - Speech to the China-Australia Chamber of Commerce, 10 June 2008. Retrieved 24 March, 2010, from

http://www.treasurer.gov.au/DisplayDocs.aspx?doc $=$ speeches $/ 2008 / 018 . h t m \& p a g e I D=005 \& \min =$ $\underline{w m s \& Y e a r}=2008 \&$ DocType $=1$

Swan, W. (2008c). "Australia, China and This Asian Century" - Speech to the Australia-China Business Council, 4 July 2008. Retrieved 7 October, 2009, from http://www.treasurer.gov.au/DisplayDocs.aspx?doc $=$ speeches $/ 2008 / 021 . h t m \& p a g e I D=005 \& m i n=$ $\underline{\text { wms \&Year }=\& \text { DocType }=1}$

Swan, W. (2008d). Chinalco's Acquisition of Shares in Rio Tinto - Press Release No. 094, 24 August 2008. Retrieved 26 November 2009 from http://www.treasurer.gov.au/DisplayDocs.aspx?doc=pressreleases/2008/094.htm\&pageID $=003 \&$ $\underline{\min }=$ wms \& Year $=2008 \&$ DocType $=0$

Swan, W. (2008e). Foreign Investment Approval: Sinosteel's Interests in Murchison Metals Ltd - Press Release No. 100, 21 September 2008. Retrieved 26 November, 2009, from http://www.treasurer.gov.au/DisplayDocs.aspx?doc=pressreleases/2008/100.htm\&pageID $=003 \&$ $\underline{\min }=$ wms \& Year $=2008 \&$ DocType $=0$

Swan, W. (2008f). Government Improves Transparency of Foreign Investment Screening Process - Press Release No. 009, 17 February 2008. Retrieved 26 November, 2009, from http://ministers.treasury.gov.au/DisplayDocs.aspx?doc $=$ pressreleases/2008/009.htm\&pageID $=003$ $\underline{\text { \&min }}=$ wms \&Year $=\&$ Doc Type $=0$

Swan, W. (2009a). Foreign Investment - Press Release No. 029, 27 March 2009. Retrieved 11 October, 2009, from http://www.treasurer.gov.au/DisplayDocs.aspx?doc=pressreleases/2009/029.htm\&pageID=003\& $\underline{\min }=$ wms \&Year $=\&$ DocType $=$

Swan, W. (2009b). Foreign Investment Decision - Press Release No. 032, 31 March 2009. Retrieved 11 October, 2009, from http://www.treasurer.gov.au/DisplayDocs.aspx?doc=pressreleases/2009/032.htm\&pageID=003\& $\underline{\min }=$ wms \&Year $=\&$ DocType $=$

Swan, W. (2009c). Foreign Investment Decision - Press Release No. 043, 23 April 2009. Retrieved 11 October, 2009, from http:/www.treasurer.gov.au/DisplayDocs.aspx?doc=pressreleases/2009/043.htm\&pageID=003\& $\underline{\min }=$ wms \&Year $=\&$ DocType $=$

Swan, W. (2009d). Foreign Investment Decision - Press Release No. 045, 8 May 2009. Retrieved 12 October, 2009, from http://www.treasurer.gov.au/DisplayDocs.aspx?doc=pressreleases/2009/045.htm\&pageID=003\& $\underline{\min }=$ wms \&Year $=\&$ DocType $=$

Thirlwell, M. (2008). Is the Foreign Investment Review Board acting fairly?, Paper Presented at Australia's Open Investment Future Symposium, 4 December 2008. Melbourne: Institute of Public Affairs.

United Nations Conference on Trade and Development. (2008). UNCTAD Handbook of Statistics 2008. Geneva: United Nations Conference on Trade and Development.

Vernon, R. (1983). Two Hungry Giants: The United States and Japan in the Quest for Oil and Gas. Cambridge, Mass.: Harvard University Press.

Wong, J., \& Chan, S. (2003). China's Outward Direct Investment: Expanding Worldwide. China: An International Journal, 1(2), 273-301.

World Bank. (1992). Strategy for African Mining. World Bank Technical Papers (No. 181). Washington, D.C.: The World Bank. 
World Trade Organisation. (2001). Protocol of Accession of the People's Republic of China, Document WT/L/432. Geneva: World Trade Organisation.

Wu, F. (2005). The Globalisation of Corporate China. NBR Analysis, 16(3), 5-29.

Xin, L., \& Findlay, C. (1985). China's Iron and Steel Industry Policy: Implications for Australia, AustraliaJapan Research Centre Research Paper No. 127. Canberra: Australia-Japan Research Centre, Australian National University.

Yilgarn Infrastructure. (2009). "Yilgarn outlines plans for \$2 billion rail project in Mid West", Media Release 7 February 2009. Perth: Yilgarn Infrastructure.

Zhang, J. (2009). Chinese seek to invest, not dominate, The Australian, 2 April 2009.

Zweig, D., \& Bi, J. (2005). China's Global Hunt for Energy. Foreign Affairs, 84(5), 25-38. 